\author{
Нікішина О.В. \\ кандидат економічних наук, докторант \\ відділ ринкових механізмів та структур \\ Інститут проблем ринку та економіко-екологічних досліджень НАН України \\ Французький бульвар, 29, м. Одеса, Україна, 65044 \\ E-mail: ksenkych@gmail.com
}

\title{
ІНТЕГРОВАНИЙ ЗЕРНОВИЙ РИНОК У ЗАБЕЗПЕЧЕННІ ЕКОНОМІЧНОЇ БЕЗПЕКИ УКРАЇНИ
}

\begin{abstract}
Узагальнено концептуальні підходи до визначення категорій «економічна безпека» та «продовольча безпека». Обґрунтовано стратегічну роль інтегрованого зернового ринку в забезпеченні економічної безпеки держави та ії складових в умовах загальносвітових інтеграційних процесів. Проведено аналіз впливу експорту зерна та продуктів його переробки на динаміку валової доданої вартості секторів економіки України, на підставі якого доведено важливу роль зернового ринку в забезпеченні зовнішньоекономічної безпеки держави.
\end{abstract}

Ключові слова: інтегрований зерновий ринок, економічна безпека, продовольча безпека, зовнішньоекономічна безпека, національні економічні інтереси, експорт зерна.

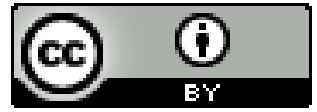

This work is licensed under a Creative Commons Attribution 4.0 International License http://creativecommons.org/licenses/by/4.0/
Постановка проблеми та її зв'язок $з$ важливими науковими та практичними завданнями. В умовах посилення глобалізаційних та інтеграційних процесів першочерговим завданням держави є забезпечення економічної безпеки (далі - ЕБ) та їі складових, зокрема продовольчої і зовнішньоекономічної безпеки, на достатньо високому рівні. Учені вважають, що сьогодні ступінь розвиненості механізму ЕБ країни повинен відповідати рівню входження в систему світогосподарських відносин [1, с. 77]. Відтак, виникає необхідність нового концептуального осмислення категорії «економічна безпека» у площині сучасних світогосподарських процесів, визначення ролі і функцій стратегічних товарних ринків, зокрема, зернового, в забезпеченні економічної безпеки держави. Актуальність постановки даної проблеми переконливо простежується через усвідомлення важливої ролі зовнішньоекономічних чинників для економічного розвитку України.

Аналіз останніх публікацій по проблемі. Дослідження певних аспектів проблеми економічної безпеки знайшли відображення в працях I. Бінька [2], С. Глазьєва [3], В. Гусакова [4], О. Олейникова [5], В. Сенчагова [6], Л. Тимошенко [1], В. Шлемка [2], О. Шнипка [7] та інших учених. Водночас недостатньо вивченими залишаються питання оцінки напрямів та ступеню впливу відтворювальних процесів, що протікають у секторах інтегрованих товарних ринків, на складові рівні ЕБ держави, що обумовило мету і завдання даної статті.

Формулювання цілей дослідження. Мета статті - обгрунтування стратегічної ролі інтегровано- го зернового ринку (далі - IЗР) в забезпеченні економічної безпеки України - окреслила низку завдань:

- узагальнення концептуальних підходів до визначення ЕБ та її складових, зокрема продовольчої та зовнішньоекономічної безпеки;

- оцінка векторів впливу IЗР на багаторівневий механізм забезпечення економічної безпеки держави;

- оцінка впливу експорту зерна та продуктів його переробки на динаміку валової доданої вартості (ВДВ) секторів економіки.

Виклад основних результатів та їх обгрунтування. За результатами проведених досліджень [8] встановлено, що ІЗР України виконує специфічні функції забезпечення продовольчої та економічної безпеки держави. Розглянемо їх детальніше.

У багаторівневій системі національної безпеки держави їі матеріальною основою, що визначає реальні можливості в забезпеченні інших видів безпеки (екологічної, військової, інформаційної, політичної, культурної та кримінальної), постає економічна безпека (рис. 1).

Економічна безпека є динамічною категорі$є ю$, що перебуває в постійному русі й видозмінюється під дією соціально-економічних, політичних та інших чинників. В ході проведеного дослідження автором виділено п'ять головних ознак, які дозволяють об'єднати сукупність неоднорідних трактувань у чотири групи, а саме (таблиця 1): (1) бажаний стан економіки, орієнтир іï розвитку; (2) забезпечення національних економічних інтересів; (3) захищеність економічних інтересів суб'єктів господарювання; (4) ефективність заходів державного регулювання. 


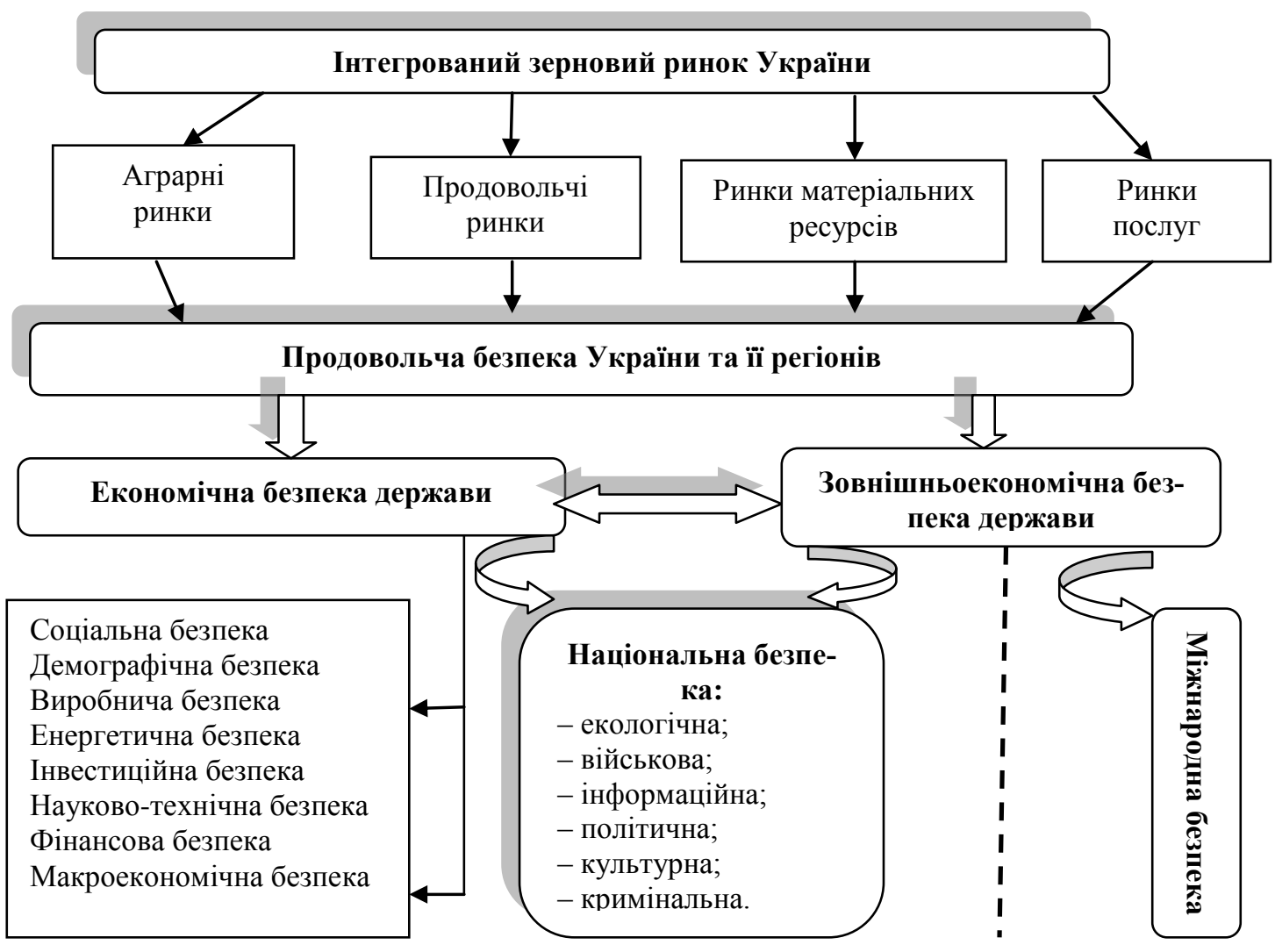

Рис. 1. Вплив інтегрованого зернового ринку на забезпечення продовольчої, зовнішньоекономічної та економічної безпеки держави*

* Складено автором із використанням джерел $[1,9]$

Слід підкреслити наявність у даному трактуванні зовнішньоекономічної складової, важливість виділення якої обумовлена активізацією глобальної конкуренції.

Представники другого підходу зміст ЕБ розкривають через реалізацію національних економічних інтересів, тобто «сукупності об'єктивних економічних потреб незалежної країни, задоволення яких забезпечує ефективне функціонування та сталий розвиток економічної системи» [10, с. 19].

На думку М. М. Єрмошенко, змістом і найважливішою функцією системи забезпечення економічної безпеки $є$ реалізація (захист) національних економічних інтересів [10, с. 20].

Ступінь захищеності економічних інтересів суб'єктів господарювання складає зміст третього концептуального підходу (див. табл. 1).

Представники четвертого підходу фокусують увагу на можливості держави впливати на рівень економічної безпеки через заходи державного регулювання. При цьому просліджується зв'язок між регуляторними заходами і процесами розширеного відтворення національного продукту.

На нашу думку, економічна безпека є керованим станом національної економіки, вектор змін якого визначається державною економічною політикою, орієнтованою на забезпечення розширеного відтво- рення складових національного продукту та подолання внутрішніх і зовнішніх загроз безпеці країни. Дане визначення синтезує в єдину площину перший і четвертий концептуальні підходи (див. табл. 1) і є дотичним до другого підходу, оскільки розробка та впровадження економічної політики держави базується на головному пріоритеті реалізації економічних інтересів держави як носія інтересів суспільства.

У працях різних учених просліджується інваріантність у поділі національної та економічної безпеки на складові. На наш погляд, найповнішу класифікацію видів безпеки здійснено Л. М. Тимошенко та Н. О. Красніковою. На їх думку, система економічної безпеки складається із десяти напрямів [1, с. 80]: соціального, демографічного, виробничого, енергетичного, фінансового, інвестиційного, науковотехнологічного, продовольчого, макро- та зовнішньоекономічного. Головні вектори впливу IЗP на безпеку держави пролягають через продовольчу та зовнішньоекономічну складові (див. рис. 1), що обумовлює доцільність їх концептуального дослідження.

Проведене дослідження дозволило автору виділити три головні ознаки до трактування терміну «nродовольча безпека» (див. табл. 1): (1) бажаний стан продовольчого ринку; (2) гарантована здатність держави щодо продовольчого забезпечення населення; (3) екологічна складова безпеки. 
Сутність категорій «економічна безпека», «продовольча безпека», «зовнішньоекономічна безпека» у трактуванні різних авторів*

\begin{tabular}{|c|c|c|}
\hline Головна ознака & Автори & Визначення дефініцій \\
\hline & & ЕКОНОМІЧНА БЕЗПЕКА \\
\hline \multirow{3}{*}{$\begin{array}{l}\text { I. Бажаний стан } \\
\text { економіки, оріє- } \\
\text { нтир її розвитку }\end{array}$} & $\begin{array}{l}\text { Шлемко В. Т., Бінь- } \\
\text { ко І. Ф. }[2, \text { с. } 8]\end{array}$ & $\begin{array}{l}\text { Такий стан національної економіки, який дозволяє зберігати стій- } \\
\text { кість до внутрішніх та зовнішніх загроз і здатен задовольнити пот- } \\
\text { реби особи, сім’ї, суспільства, держави }\end{array}$ \\
\hline & $\begin{array}{l}\text { Глазьєв С. Ю. } \\
{[3, \text { с.3] }}\end{array}$ & $\begin{array}{l}\text { Стан економіки та продуктивних сил суспільства з точки зору мож- } \\
\text { ливостей самостійного забезпечення стійкого соціально- } \\
\text { економічного розвитку держави, підтримки необхідного рівня наці- } \\
\text { ональної безпеки держави, а також потрібного рівня конкурентосп- } \\
\text { роможності національної економіки в умовах глобальної конкурен- } \\
\text { ції }\end{array}$ \\
\hline & $\begin{array}{l}\text { Методичні рекоме- } \\
\text { ндації щодо розра- } \\
\text { хунку рівня еконо- } \\
\text { мічної безпеки } \\
\text { України [9] }\end{array}$ & $\begin{array}{l}\text { Стан національної економіки, який дає змогу зберігати стійкість до } \\
\text { внутрішніх та зовнішніх загроз, забезпечувати високу конкурентос- } \\
\text { проможність у світовому економічному середовищі і характеризує } \\
\text { здатність національної економіки до сталого та збалансованого зро- } \\
\text { стання }\end{array}$ \\
\hline \multirow{2}{*}{$\begin{array}{l}\text { II. Забезпечення } \\
\text { національних } \\
\text { економічних } \\
\text { інтересів }\end{array}$} & $\begin{array}{l}\text { Сенчагов В. К. } \\
{[6, \text { с. } 12]}\end{array}$ & $\begin{array}{l}\text { Стан економіки та інститутів влади, при яких забезпечується гаран- } \\
\text { тований захист національних інтересів, соціальна спрямованість } \\
\text { політики, достатній оборонний потенціал навіть за несприятливих } \\
\text { умовах розвитку внутрішніх та зовнішніх процесів }\end{array}$ \\
\hline & $\begin{array}{l}\text { Єрмошенко М. М. } \\
{[10, \text { с. } 5]}\end{array}$ & $\begin{array}{l}\text { Стан економіки, при якому національні економічні інтереси захи- } \\
\text { щені від внутрішніх і зовнішніх загроз. Реалізація (захист) націона- } \\
\text { льних економічних інтересів є змістом забезпечення економічної } \\
\text { безпеки держави. }\end{array}$ \\
\hline \multirow{2}{*}{$\begin{array}{l}\text { III. Ступінь за- } \\
\text { хищеності еко- } \\
\text { номічних інте- } \\
\text { ресів суб'єктів } \\
\text { господарювання }\end{array}$} & $\begin{array}{l}\text { Шнипко О. С. } \\
{[7, \text { с. } 79]}\end{array}$ & $\begin{array}{l}\text { Стан захищеності життєво важливих інтересів системи від недобро- } \\
\text { совісної конкуренції, протиправної діяльності кримінальних форму- } \\
\text { вань та окремих осіб, здатність протистояти внутрішнім і зовнішнім } \\
\text { загрозам, зберігати стабільність функціонування та розвитку відпо- } \\
\text { відно до його стратегічних цілей }\end{array}$ \\
\hline & $\begin{array}{l}\text { Гусаков В. Г. } \\
\text { (економічний гло- } \\
\text { сарій) }[11]\end{array}$ & $\begin{array}{l}\text { Запобігання розголошенню конфіденційної економічної інформації } \\
\text { суб'єктів господарювання, порушення комерційної таємниці, здійс- } \\
\text { нення економічних диверсій. }\end{array}$ \\
\hline \multirow[b]{2}{*}{$\begin{array}{l}\text { IV. Результа- } \\
\text { тивність заходів } \\
\text { державного ре- } \\
\text { гулювання }\end{array}$} & $\begin{array}{l}\text { Олійников С. А. } \\
{[5, \text { с. } 15]}\end{array}$ & $\begin{array}{l}\text { Можливість народного господарства забезпечувати стабільний пос- } \\
\text { туповий розвиток і відповідний захист економічними методами як } \\
\text { інтересів окремої людини, так і держави в цілому }\end{array}$ \\
\hline & $\begin{array}{l}\text { Кулікова І. М., Ря- } \\
\text { бова Т. Ф. (економі- } \\
\text { чний глосарій) [11] }\end{array}$ & $\begin{array}{l}\text { Комплекс заходів, який включає: (а) необхідний рівень розвитку } \\
\text { продуктивних сил, здатний забезпечити вагому частку натуральних } \\
\text { і вартісних елементів розширеного відтворення національного про- } \\
\text { дукту; (б) внутрішню соціально-політичну основу - рівень суспіль- } \\
\text { ної згоди щодо довгострокових національних цілей, що робить мо- } \\
\text { жливим вироблення і прийняття стратегії соціально-економічного } \\
\text { розвитку, втілювану в життя через державну політику }\end{array}$ \\
\hline \multicolumn{3}{|r|}{ ПРОДОВОЛЬЧА БЕЗПЕКА } \\
\hline \multirow{3}{*}{$\begin{array}{l}\text { I. Стан економі- } \\
\text { ки, продоволь- } \\
\text { чого ринку }\end{array}$} & $\begin{array}{l}\text { Гусаков В. Г., } \\
\text { Є. І. Дереза та ін. } \\
\text { (економічний гло- } \\
\text { сарій) }[11]\end{array}$ & $\begin{array}{l}\text { Стан економіки, при якому, незалежно від кон'юнктури світових } \\
\text { ринків, гарантується стабільне забезпечення населення продовольс- } \\
\text { твом у кількості, що відповідає науково обгрунтованим параметрам } \\
\text { (пропозиція), } 3 \text { одного боку, і створюються умови для підтримки } \\
\text { споживання на рівні медичних норм (попит), що відповідає умовам } \\
\text { розширеного відтворення населення, з іншого боку. }\end{array}$ \\
\hline & Гусаков В. Г. [4] & $\begin{array}{l}\text { Стан продовольчого ринку країни або групи країн, а також світово- } \\
\text { го ринку, при якому забезпечується гарантований доступ всіх соціа- } \\
\text { льних груп населення до життєво важливих продуктів харчування в } \\
\text { будь-який час і обсягах, достатніх для досягнення медичних норм } \\
\text { споживання }\end{array}$ \\
\hline & $\begin{array}{l}\text { Методичні рекоме- } \\
\text { ндації щодо розра- } \\
\text { хунку рівня еконо- } \\
\text { мічної безпеки } \\
\text { України [9] }\end{array}$ & $\begin{array}{l}\text { Стан виробництва продуктів харчування в країні, що здатний пов- } \\
\text { ною мірою забезпечити потреби кожного члена суспільства в про- } \\
\text { довольстві належної якості за умови його збалансованості та досту- } \\
\text { пності для кожного члена суспільства }\end{array}$ \\
\hline
\end{tabular}


Продовження таблиці 1

\begin{tabular}{|c|c|c|c|}
\hline \multirow{3}{*}{$\begin{array}{l}\text { II. Гарантована } \\
\text { здатність держа- } \\
\text { ви щодо продо- } \\
\text { вольчого забез- } \\
\text { печення насе- } \\
\text { лення }\end{array}$} & \multicolumn{2}{|c|}{$\begin{array}{l}\text { Закон України «Про } \\
\text { державну підтримку } \\
\text { сільського госпо- } \\
\text { дарства України», } \\
\text { ст. } 2 \text { [12] }\end{array}$} & $\begin{array}{l}\text { Захищеність життєвих інтересів людини, яка виражається у гаран- } \\
\text { туванні державою безперешкодного економічного доступу людини } \\
\text { до продуктів харчування з метою підтримання їі звичайної життєвої } \\
\text { діяльності }\end{array}$ \\
\hline & \multicolumn{2}{|c|}{ Гусаков В. Г. $[4,13]$} & $\begin{array}{l}\text { Чітко функціонуюча система, що забезпечує всі верстви населення } \\
\text { продуктами харчування за прийнятими фізіологічними нормами за } \\
\text { рахунок власного виробництва і раціоналізації необхідного імпорту } \\
\text { тих продуктів, для виробництва яких немає внутрішніх умов (визна- } \\
\text { чення } Ф A O)\end{array}$ \\
\hline & \multicolumn{2}{|c|}{$\begin{array}{l}\text { Хорунжий М. Й. } \\
{[14, \text { с. } 15]}\end{array}$} & $\begin{array}{l}\text { Здатність держави за будь-яких умов гарантувати й забезпечувати } \\
\text { потреби населення в продовольстві на рівні наукового обгрунтов- } \\
\text { ного споживання у відповідності до його платоспроможного попиту } \\
\text { відносно цін, що склалися на продовольчому ринку; складова час- } \\
\text { тина аграрної та економічної політики держави. }\end{array}$ \\
\hline $\begin{array}{l}\text { III. Екологічна } \\
\text { складова безпе- } \\
\text { ки }\end{array}$ & \multicolumn{2}{|c|}{$\begin{array}{l}\text { Буркинський Б. В., } \\
\text { Ковальова Н. Г. } \\
{[15, \text { с. } 113]}\end{array}$} & $\begin{array}{l}\text { Продовольчо-екологічна безпека передбачає виробництво екологіч- } \\
\text { но чистої продовольчої продукції на основі чистого природного } \\
\text { середовища й інноваційних технологій }\end{array}$ \\
\hline \multicolumn{4}{|c|}{ ЗОВНІШНЬОЕКОНОМІЧНА БЕЗПЕКА } \\
\hline \multicolumn{2}{|c|}{$\begin{array}{l}\text { Методичні рекомендації } \\
\text { щодо розрахунку рівня } \\
\text { економічної безпеки } \\
\text { України [9] }\end{array}$} & \multicolumn{2}{|c|}{$\begin{array}{l}\text { Стан відповідності зовнішньоекономічної діяльності національним економічним } \\
\text { інтересам, що забезпечує мінімізацію збитків держави від дії негативних зовнішніх } \\
\text { економічних чинників та створення сприятливих умов для розвитку економіки } \\
\text { завдяки їі активній участі у світовому розподілі праці }\end{array}$} \\
\hline Гусаков В. Г. [4] & \multicolumn{3}{|c|}{$\begin{array}{l}\text { Міжнародна продовольча безпека забезпечується шляхом національних систем регулю- } \\
\text { вання аграрного виробництва та включає два напрями: (1) дотримання політики сталого } \\
\text { продовольчого, сільськогосподарського розвитку на територіях } 3 \text { високим або низьким по- } \\
\text { тенціалом, максимальне використання ресурсів і національного агроекономічного потенці- } \\
\text { алу кожної держави, що, в кінцевому рахунку, веде до збільшення загальносвітових ресур- } \\
\text { сів продовольства; (2) вдосконалення продовольчої та торговельної політики з метою дося- } \\
\text { гнення продовольчої безпеки шляхом створення торгової системи, орієнтованої на світ-- } \\
\text { вий ринок. }\end{array}$} \\
\hline
\end{tabular}

Найпоширенішим є другий підхід, в межах якого продовольча безпека інтерпретується як чітко функціонуюча система, що забезпечує всі верстви населення продуктами харчування за прийнятими фізіологічними нормами за рахунок власного виробництва і раціоналізації необхідного імпорту тих продуктів, для виробництва яких немає внутрішніх умов (визначення ФАО) [4, 13]. Взаємозв'язок продовольчої та зовнішньоекономічної безпеки просліджується в дефініції «міжнародна продовольча безпека», яка фокусує увагу на ефективному використанні агроекономічного потенціалу держав та вдосконаленні продовольчої торговельної політики.

Зовнішньоекономічна безпека, з одного боку, $\epsilon$ складовою економічної безпеки, з іншого, самостійним зовнішнім невід'ємним від їі внутрішньої сфери блоком, що взаємодіє з усіма іншими підсистемами національної безпеки (див. рис. 1). Її виокремлення в окрему підсистему обумовлено посиленням світових глобалізаційних та інтеграційних процесів, стратегічним значенням зовнішніх чинників для економічного розвитку нашої держави.

Найповніше визначення зовнішньоекономічної безпеки наведено в Методичних рекомендаціях щодо розрахунку рівня економічної безпеки України [9]: стан відповідності зовнішньоекономічної діяльності національним економічним інтересам, що забезпечує мінімізацію збитків держави від дії негатив- них зовнішніх економічних чинників та створення сприятливих умов для розвитку економіки завдяки іiі активній участі у світовому розподілі праці (див. табл. 1). В ході розробки механізму забезпечення безпеки доцільно обгрунтувати комплекс заходів, орієнтованих на реалізацію економічних можливостей, наданих країні світогосподарською системою, за одночасної нейтралізації супутніх негативних тенденцій i загроз. На наш погляд, концептуальним базисом для вибору прикладних заходів $є$ принцип узгодження глобальних, національних і регіональних інтересів.

Слід відзначити, що більшість реальних і потенційних загроз національній безпеці України в економічній сфері, визначених Законом України «Про основи національної безпеки» № 964-IV (ст. 7) [16], повністю або частково можна віднести до загроз зовнішніх, зокрема: істотне скорочення ВВП; недостатні темпи відтворювальних процесів та подолання структурної деформації в економіці; критична залежність національної економіки від кон'юнктури зовнішніх ринків, низькі темпи розширення внутрішнього ринку; нераціональна структура експорту 3 переважно сировинним характером та низькою питомою вагою продукції з високою часткою доданої вартості та ін.

Мета забезпечення ЕБ полягає в ліквідації або мінімізації загроз, реалізації потенційних можливостей поліпшення стану національної безпеки шляхом ефективного функціонування інтегрованих рин- 
ків, передусім у реальному секторі економіки. Існуючі деформації відтворювальних процесів у секторах таких ринків обумовлюють необхідність розробки та впровадження виваженої державної політики з питань економічної безпеки для підтримання іiі на сталому рівні або перманентному підвищенні (в кількісному вимірі).

Інтегрований зерновий ринок України є базовою мезосистемою, фундаментом системи суміжних $\mathrm{i}$ пов'язаних ринків, яка об'єднує насіннєвий ринок, сфери фуражного (ринок комбікормів), продовольчого (ринки борошна, круп, хлібобулочних, макаронних i борошняних кондитерських виробів) та промислового (ринки спирту, крохмалю, медичних препаратів тощо) використання зерна (див. рис. 1). Як системоутворюючий ринок національного агропродовольчого ринку, ІЗР задає основні параметри діяльності, з одного боку, ресурсозабезпечуючим ринкам (сільськогосподарської техніки, добрив, насіння, засобів захисту рослин тощо), з іншого - споживчим і переробним ринкам (ринки тваринницької продукції, хлібних, м'ясо-молочних продуктів, кормів для тварин і риби), а також ринкам послуг (елеваторних, транспортних, страхових тощо).

На думку А. І. Алтухова, «з урахуванням масштабів і повноти елементів економічних відносин зерновий ринок може виступати в якості своєрідної моделі розвитку для інших ринків сільськогосподарської продукції, сировини і продовольства...» [17, с. 86]. Практика свідчить, що кризові прояви на IЗР, зокрема, цінові збурення та цінова волатильність, породжують аналогічні процеси не тільки в системі суміжних ринків, але й на інших ринках країни (зокрема, тваринницької продукції, м'яса, молока та ін.). На цінові сигнали інтегрованого зернового ринку реагують не тільки окремі продуктові ринки, але й значна частина промислових ринків економічної системи; загалом ціни зернових культур визначають рівень цін близько 40 \% продовольчих товарів.

Графічна інтерпретація взаємозв'язку між темпами зміни ланцюгових індексів цін зернових культур і споживчих цін продуктів харчування (рис. 2) дозволила встановити такі тенденції: (1) глибина цінових коливань на ІЗР є вищою порівняно $з$ волатильністю цін на ринках продовольчих товарів; (2) спостерігається річне відставання цінових стрибків на ринках харчових продуктів від цінових хвиль базового аграрного ринку. Так, зростання цін зерна у 2007 р. порівняно 3 попереднім роком на 61,8 \% обумовило збільшення споживчих цін продуктів харчування у 2008 р. на $36,7 \%$, у т.ч. цін м'ясних і молочних продуктів на $39,4 \%$ і 31,2 \% відповідно. Натомість зменшення цін зернових культур у 2013 р. на $16 \%$ супроводжувалося незначним скороченням цін продовольчих товарів (на 2,4 \%).

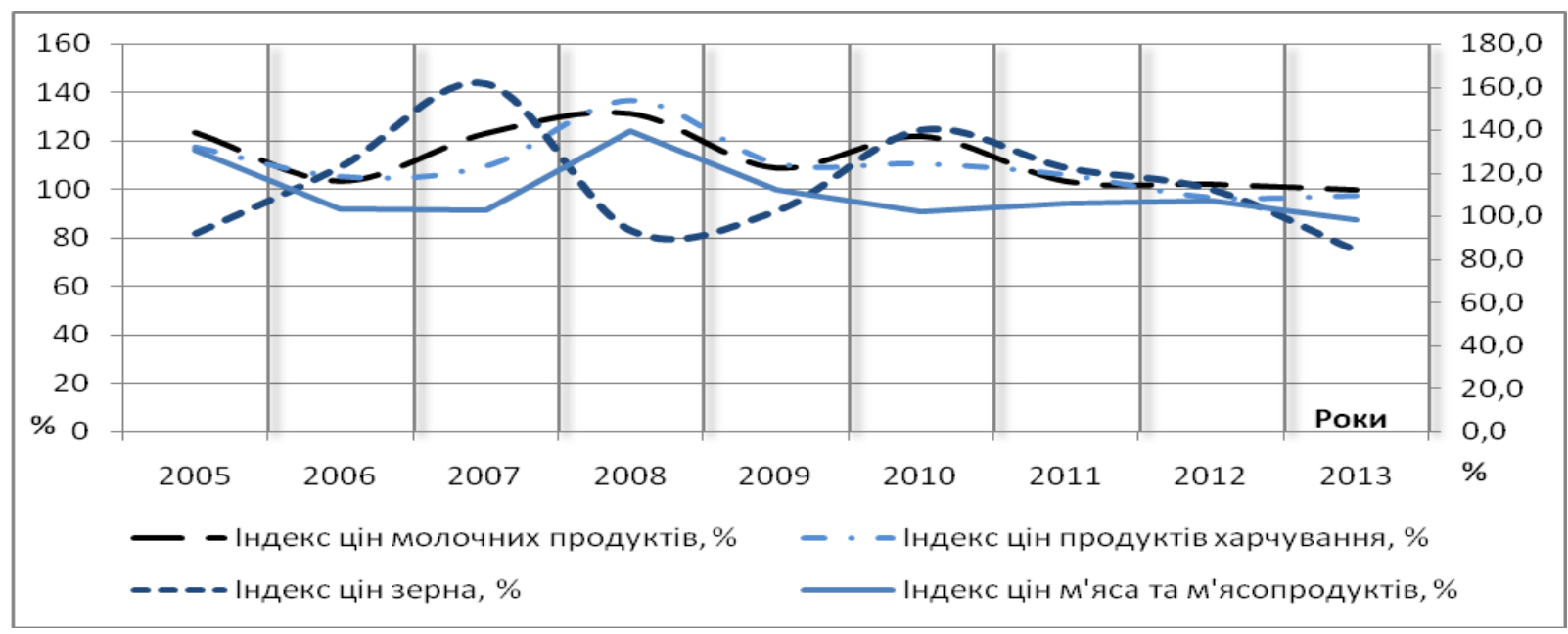

Рис. 2. Темпи зростання ланцюгових індексів цін зернових культур та споживчих цін продуктів харчування"

*Побудовано автором за даними Державної служби статистики України [18].

Як базовий ринок мезосистеми суміжних i пов'язаних ринків, ІЗР має здатність до генерування потужного мультиплікативного ефекту для сталого відтворювального розвитку даних ринків (див. рис. 1.). За оцінкою А. І. Алтухова, одне робоче місце у зерновиробництві створює основу для діяльності 710 місць в інших сферах економіки [17, с. 81]. Відповідно, мультиплікативний ефект від збалансованого функціонування інтегрованого ринку зерна дасть можливість успішно вирішувати не тільки агропродовольчі, але й структурні та загальноекономічні завдан- ня, зокрема, підвищення ефективності багаторівневого механізму економічної безпеки держави. Оскільки всі види безпеки органічно поєднані в систему та взаємообумовлені, то очевидним є одночасний вплив IЗР на декілька видів економічної безпеки.

Наприклад, зростання цін на зерно продукує збільшення цін близько 40 \% продуктів харчування, що обумовлює скорочення економічної доступності продовольства для населення на рівні життєзабезпечення, впливаючи на продовольчу, соціальну та демографічну складові економічної безпеки. 3 іншого бо- 
ку, сировинна спрямованість вітчизняного агроекспорту, зменшення обсягів виробництва та експорту зернопродуктів, зростаючий імпорт продовольчих товарів одночасно негативно відображаються на рівнях продовольчої, виробничої, макроекономічної, фінансової та зовнішньоекономічної безпеки держави (див. рис. 1). На практиці деструктивними проявами нераціональної структури агроекспорту є знижувальний тренд продовольчого самозабезпечення України, зростаюча залежність внутрішніх ринків від імпорту продовольства та цінової кон'юнктури світового ринку, втрати валютної виручки від експорту високоякісного екологічно безпечного зерна за цінами, нижчими світових, перманентно знижувальний рівень фізичної та економічної доступності продовольства для малозабезпечених груп населення тощо.

Слід виділити негативний вплив асиметричності вітчизняного агроекспорту на рівень виробничої безпеки, дотримання якої є передумовою ефективного функціонування реального сектору економіки. Виробнича безпека характеризує стан виробничої сфери держави, за якого забезпечується максимально ефективне використання наявних виробничих потужностей у країні, їх модернізація та розширене відтворення, зростання рівня інноваційності виробництва та підвищення рівня конкурентоспроможності національної економіки [9]. Сьогодні рівень завантаження зернопереробних підприємств складає в середньому 25-30 \%, для усіх секторів IЗР (окрім інфраструктурного) характерним є просте та звужене відтворення матеріальних, фінансових і трудових ресурсів, інноваційний потенціал ринку майже не використовується. Порушення в товарно-фінансово-інформаційних потоках продукують структурні та фінансові деформації відтворювальних процесів, відтак, і загрози макроекономічній безпеці держави. Дана складова безпеки характеризує стан економіки, за якого досягається збалансованість макроекономічних відтворювальних пропорцій [9]. Відповідно, асиметричність розвитку відтворювальних систем ринків, суміжних до ринку зерна та продуктів його переробки, які є структуроутворюючими елементами національної економіки, порушує іiї сталий і збалансований розвиток.

Домінуючий сировинний вектор українського агроекспорту негативно позначається на рівні зовнішньоекономічної безпеки держави. Проблема переважаючого сировинного експорту полягає в тому, що країна на зовнішньому ринку експортує продукцією 3 низькою часткою доданої вартості, а імпортує товари 3 високою іiі часткою. Різниця у вартостях складає транснаціональний податок, який сплачує держава сировинний експортер. Він спрямовується на розвиток переробних галузей і створення додаткових робочих місць у країнах, які в обмін на українську сільськогосподарську сировину ввозять нам промислові напівфабрикати і готову продукцію [19, с. 73]. Водночас внутрішні продовольчі ринки поступово перетворюються на ринки із нерозвиненим виробничим сектором, які неспроможні в повній мірі реалізувати базову відтворювальну функцію, відтак, забезпечити здатність національної економіки до сталого та збалансованого зростання, що $є$ змістом економічної безпеки держави (див. табл. 1).

За статистичними даними, частка експорту зернових культур (підгрупа 10) у загальному обсязі вітчизняного експорту перманентно зростає: 3 4,04\% в 2005 р. до 10,1\% в 2013 р. та 12,1\% в 2014 р. Питома вага експорту готових зернових продуктів (підгрупа 19) теж збільшується (з 0,29\% в 2005 р. до $0,7 \%$ в 2013-2014 pр.), однак їі приріст (на 0,4 \% в 2014 р. порівняно з 2008 р.) є нижчим порівняно з аналогічним показником для зерна (на 6,6 \%). Тенденція до перевищення темпів експорту сировини над експортом продуктів іiї переробки з високою доданою вартістю притаманна багатьом продовольчим ринкам країни. У якості оцінки впливу ІЗР на рівень зовнішньоекономічної безпеки держави використаємо динаміку сальдо зовнішньої торгівлі зерном і продуктами його переробки (таблиця 2).

Таблиця 2

Сальдо зовнішньої торгівлі України зерном і продуктами його переробки, млн. дол. США*

\begin{tabular}{|l|c|c|c|c|c|c|c|c|c|}
\hline \multirow{2}{*}{ Сальдо зовнішньої торгівлі } & \multicolumn{7}{|c|}{ Роки } \\
\cline { 2 - 11 } & 2005 & 2006 & 2007 & 2008 & 2009 & 2010 & 2011 & 2012 & 2013 \\
\hline $\begin{array}{l}\text { 1. Продуктами рослинного } \\
\text { походження (група II) }\end{array}$ & 1170,4 & 1279,5 & 865,9 & 4114,9 & 3774,9 & 2412,6 & 3716,1 & 6784,2 & 6206,2 \\
\hline $\begin{array}{l}\text { 1.1. Зерновими культурами } \\
\text { (підгрупа 10) }\end{array}$ & 1326,6 & 1294,8 & 677,1 & 3557,3 & 3457,7 & 2321,5 & 3397,1 & 6750,7 & 6064,8 \\
\hline $\begin{array}{l}\text { 1.2. За виключенням зерно- } \\
\text { вих культур }\end{array}$ & $-156,2$ & $-15,3$ & 188,7 & 557,6 & 317,3 & 91,1 & 319,0 & 33,5 & 141,4 \\
\hline $\begin{array}{l}\text { 2. Готовими харчовими } \\
\text { продуктами (група IV) }\end{array}$ & $-163,0$ & $-261,0$ & $-35,0$ & $-161,0$ & 54,0 & 66,0 & $-88,0$ & 528,5 & 338,4 \\
\hline $\begin{array}{l}2.1 . \text { Продуктами із зерно- } \\
\text { вих культур (підгрупа 19) }\end{array}$ & 44,8 & 40,0 & 56,6 & 92,0 & 109,0 & 128,3 & 174,0 & 206,6 & 197,3 \\
\hline $\begin{array}{l}2.2 . \text { За виключенням проду- } \\
\text { ктів із зернових культур }\end{array}$ & $-207,8$ & $-301,0$ & $-91,6$ & $-253,0$ & $-55,0$ & $-62,3$ & $-262,0$ & 321,9 & 141,0 \\
\hline
\end{tabular}


Продовження таблиці 2

\begin{tabular}{|c|c|c|c|c|c|c|c|c|c|}
\hline $\begin{array}{l}\text { 3. Залишків і відходів хар- } \\
\text { чової промисловості; гото- } \\
\text { вих кормів для тварин (пі- } \\
\text { дгрупа 23) }\end{array}$ & 27,9 & 14,4 & 160,9 & 244,8 & 115,5 & 270,6 & 379,5 & 618,1 & 637,3 \\
\hline $\begin{array}{l}\text { 3.1. Готових кормів для } \\
\text { тварин (підгрупа 2309) }\end{array}$ & $-71,5$ & $-92,5$ & $-73,2$ & $-39,9$ & $-151,8$ & $-172,8$ & $-201,7$ & $-232,0$ & $-249,4$ \\
\hline $\begin{array}{l}\text { 3.2. За виключенням гото- } \\
\text { вих кормів для тварин }\end{array}$ & 99,4 & 106,9 & 234,1 & 284,7 & 267,3 & 443,5 & 581,2 & 850,1 & 886,7 \\
\hline
\end{tabular}

"Розраховано автором за даними Державної служби статистики України [18]

Позитивне сальдо продуктів рослинного походження (група II) на 97,7 \% забезпечують зернові культури; за виключенням підгрупи 10 сальдо зовнішньої торгівлі групи II склало б усього 141,4 млн. дол. (2,3 \% від рівня 2013 р.). Частка зернових продуктів (підгрупа 19) у формуванні позитивного сальдо готових харчових продуктів (група IV) в 20122013 pр. досягла 39,1\% і 58,3 \% відповідно. На тлі нестабільного сальдо товарів групи IV позитивну динаміку має сальдо зовнішньої торгівлі товарів підгрупи 19 (див. табл. 2). Саме воно у 2009-2010 рр. забезпечило позитивне значення сальдо харчових продуктів; за виключенням зернових продуктів вихідний показник мав би від'ємне значення (-55 і -62,3 млн. дол. відповідно). На тлі позитивного зростаючого сальдо товарів підгрупи 23 стабільно негативну динаміку має сальдо готових кормів для тварин; за ви- ключенням даної товарної позиції сальдо зовнішньої торгівлі товарів підгрупи 23 було б майже на $40 \%$ вищим.

У графічній інтерпретації криві сальдо продуктів рослинного походження і зернових культур практично співпадають (рис. 3). Подальше дослідження впливу зовнішньої торгівлі даних товарів на ВДВ сільського господарства дозволило визначити таку особливість: за період 2005-2009 рр. динаміка змін досліджуваних показників $є$ одновекторною. Водночас майже подвійне зростання сальдо зернових культур у 2012 р. супроводжувалося зростанням ВДВ аграрного сектору економіки України всього на $2,4 \%$, що $є$ свідченням невідповідності сировинної орієнтації агроекспорту національним економічним інтересам.

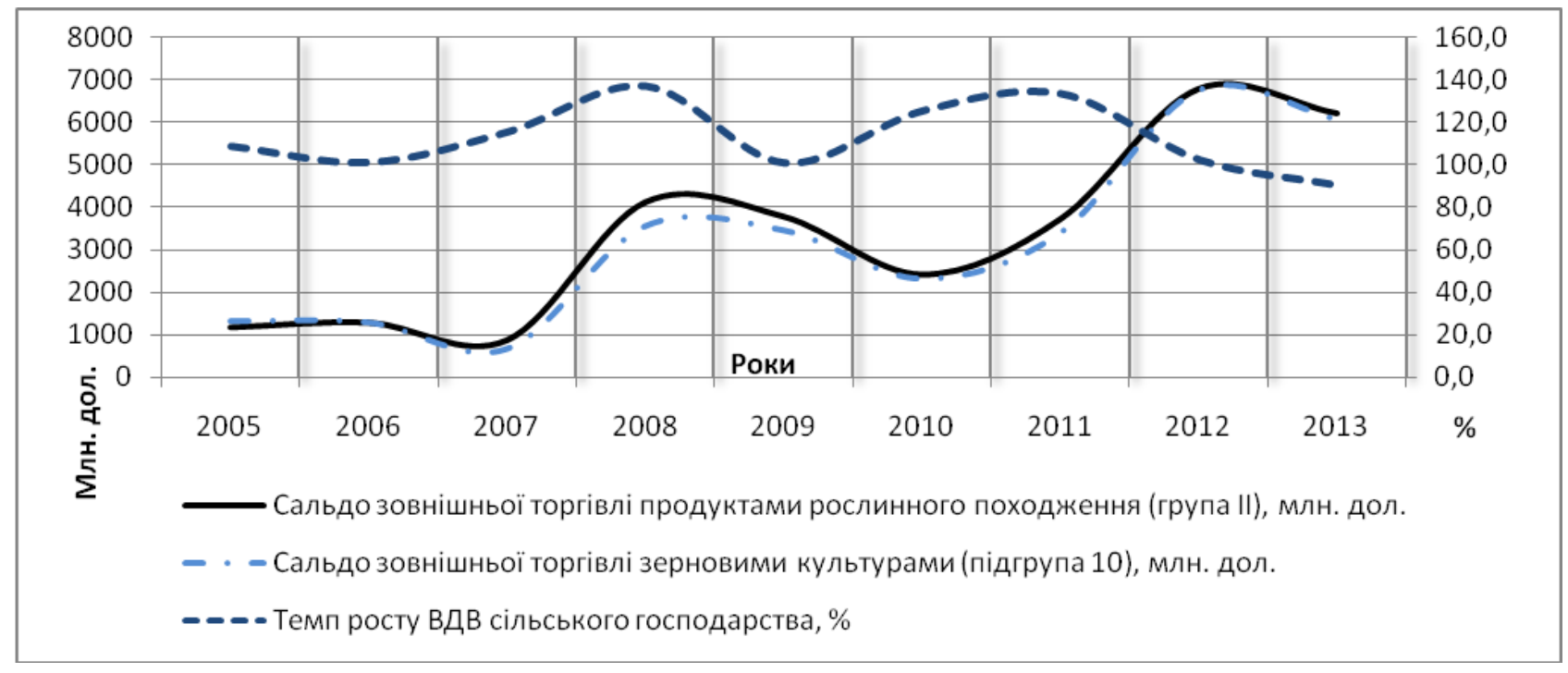

Рис. 3. Динаміка ВДВ сільського господарства України і сальдо зовнішньої торгівлі продуктами рослинного походження та зерновими культурами*

*Побудовано автором за даними Державної служби статистики України [18]

У графічній інтерпретації крива сальдо готових харчових продуктів $є$ варіативною, охоплюючи неоднорідну сукупність позитивних і від'ємних значень (рис. 4). Навпаки, крива сальдо зовнішньої торгівлі зерновими продуктами $є$ значно стабільнішою. На відміну від попереднього варіанту, динаміка змін сальдо харчових продуктів і ВДВ переробної промисловості різновекторна і важкопрогнозована, при цьому глибина коливань першого показника $є$ значно вищою порівняно 3 другим. Так, стрімке зростання сальдо зовнішньої торгівлі харчових продуктів із високою доданою вартістю з -88 млн. дол. у 2011 р. до 529 млн. дол. у 2012 р. супроводжувалося незначним збільшенням ВДВ на 7,2 \%, водночас темп скорочення сальдо товарів групи IV у 2013 р. (на 36\%) був значно вищим аналогічного показника для ВДВ переробної промисловості (на $6 \%$ ). 


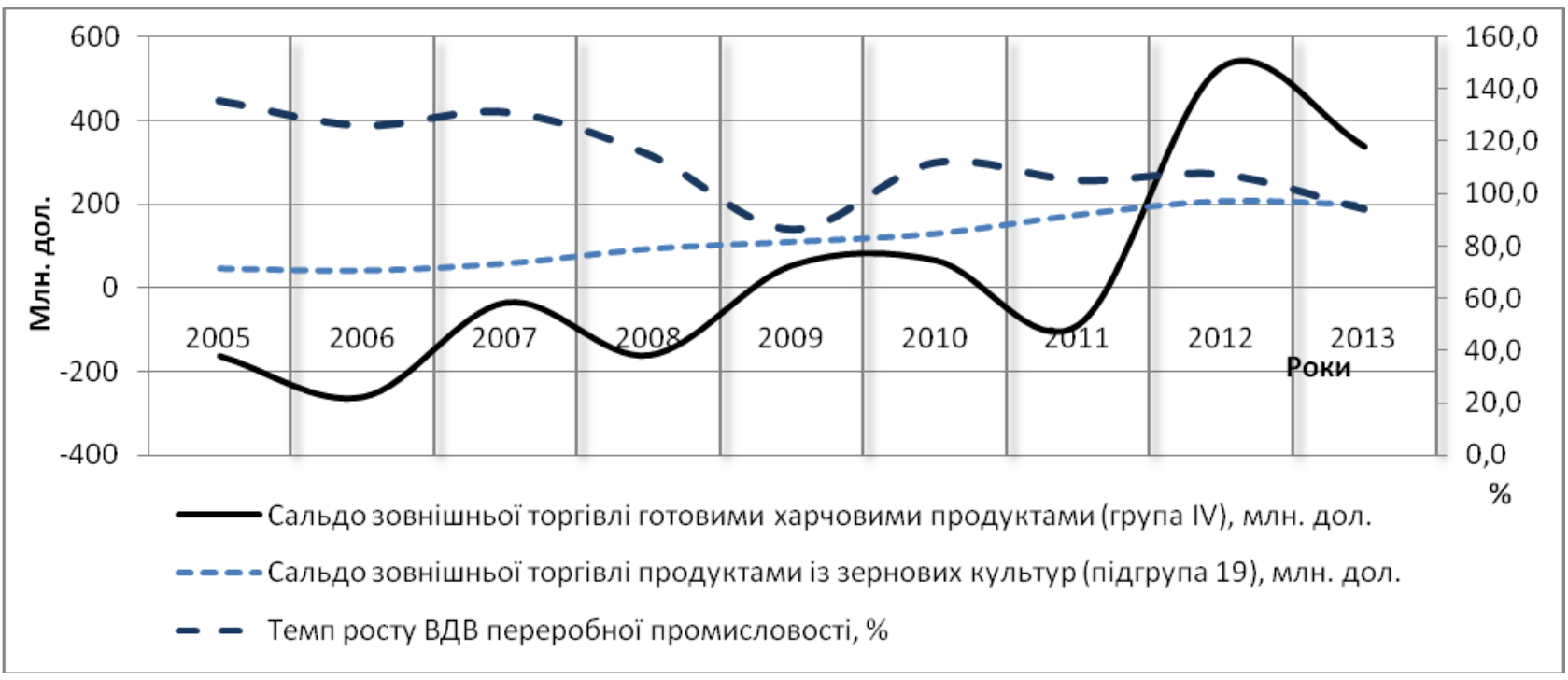

Рис. 4. Динаміка ВДВ переробної промисловості України і сальдо зовнішньої торгівлі готовими харчовими продуктами та зерновими продуктами*

*Побудовано автором за даними Державної служби статистики України [18]

Р. П. Мудрак за результатами кореляційнорегресійного аналізу доводить правомірність такої гіпотези: періоди зростання імпорту продовольства мають прямий зв'язок з періодами підвищення темпів економічного зростання української економіки. Прискорення темпів економічного зростання супроводжується збільшенням споживчого попиту населення на цінні харчові продукти, який задовольняється, передусім, за рахунок імпорту, а не нарощування внутрішньої пропозиції товарів. Учений вважає, що головною причиною такого явища є структурні диспропорції вітчизняної економіки - переважання галузей групи «А» над галузями групи «Б» [19, с. 74-75].
Графічна інтерпретація взаємозв'язку між темпами зростання ВДВ національної економіки та імпортом готових харчових продуктів (група IV) підтверджує гіпотезу Р. П. Мудрака, особливо в першому часовому періоді (2005-2010 pp.). Водночас кореляційного зв'язку між темпами зростання ВДВ та імпортом зернових продуктів (підгрупа 19) не просліджується, що свідчить про здатність вітчизняних виробників у періоди зростання споживчого попиту наростити обсяги випуску товарів (рис. 5). Натомість стрімко зростає імпорт готових кормів для тварин; його тренд не залежить від динаміки ВДВ економіки.

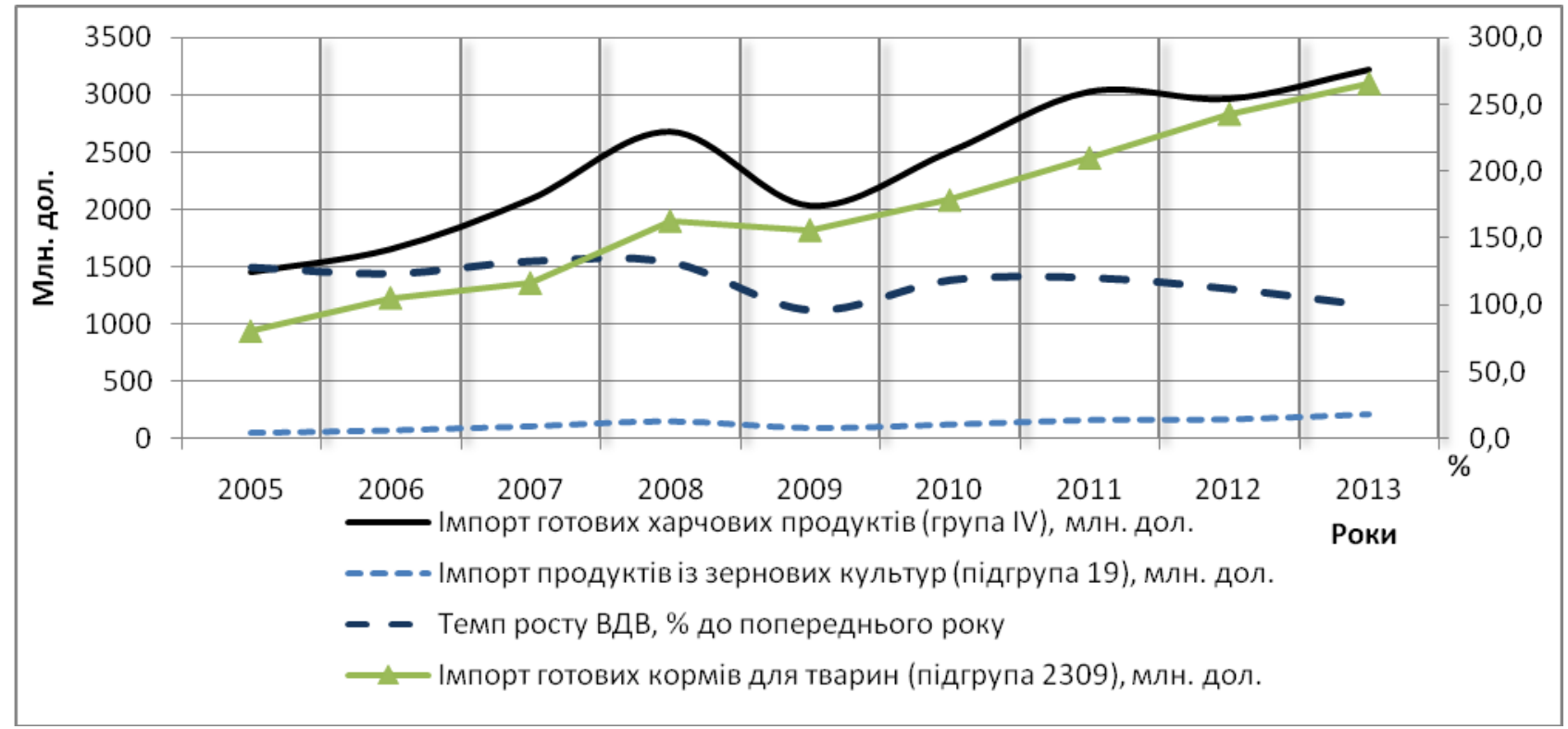

Рис. 5. Динаміка ВДВ економіки України та імпорту готових харчових продуктів і продуктів із зернових культур*

*Побудовано автором за даними Державної служби статистики України [18] 
Результати оцінки впливу ІЗР на рівень зовнішньоекономічної безпеки свідчать про пасивну форму інтеграційної політики України, характерними рисами якої $є$ реалізація економічних інтересів інших держав або інтеграційних об'єднань, вузького кола представників держави, політичних угрупувань тощо. За пасивної форми метою інтеграції виступає не економічне зростання держави, а безпосередньо інтеграційний процес як самоціль [20, с. 199]. Сировинна спрямованість вітчизняного агроекспорту, передусім зернового, відповідає фінансовим інтересам трейдерів й іноземних ТНК, однак не держави. Вона активізує дію зовнішніх загроз національній безпеці. 3 іншого боку, незавершеність внутрішніх соціальноекономічних перетворень співпала у часі 3 об'єктивною необхідністю інтеграції України в світогосподарські структури, що продукує достатньо обгрунтовані ризики іiі перетворення на сировинний придаток розвинутих країн $[19$, с. 71$]$.

Теоретичним базисом розбудови механізму ЕБ може стати активна інтеграційна політика держави. Вона впроваджується під впливом виваженої державної соціально-економічної політики, в якій інтеграція виконує не головну, а допоміжну роль - підсилює механізми активізації товарно-фінансового обігу з метою залучення капіталу в національну економіку, розвитку іiі ринків, передусім реального сектору, підвищення рівня життя і добробуту населення [20, c. 199]. Реалізація активної інтеграційної політики дозволить забезпечити, по-перше, високий рівень зовнішньоекономічної безпеки держави, по-друге, здатність національної економіки до сталого і збалансованого зростання шляхом розвитку їі структуроутворюючих елементів - товарних ринків, що $є$ змістом і метою економічної безпеки (див. табл. 1.).

Висновки та перспективи подальших досліджень. У ході дослідження автором розкрито зміст економічної безпеки у площині чотирьох концептуальних підходів: (1) бажаний стан економіки, (2) забезпечення національних економічних інтересів; (3) захищеність економічних інтересів суб'єктів господарювання; (4) ефективність заходів державного регулювання. Запропоновано авторське визначення категорії «економічна безпека», що поєднує перший і четвертий концептуальний підходи. Обгрунтовано залежність ЕБ від зовнішньоекономічної безпеки держави.

Дослідженням встановлено, що головні вектори впливу IЗР на економічну безпеку держави пролягають через продовольчу та зовнішньоекономічну складові. Функція зернового ринку щодо забезпечення продовольчої безпеки реалізується шляхом впливу відтворювальних процесів, що протікають у надрах його секторів, на розвиток суміжних та пов'язаних агропродовольчих ринків макроекономічної системи для забезпечення фізичної й економічної доступності продовольства. Характерним є одночасний взаємообумовлений вплив зернового ринку на декілька складових економічної безпеки, а саме: продовольчу, соціальну, демографічну, виробничу, макроекономічну, фінансову та зовнішньоекономічну безпеку.

Для оцінки впливу ІЗР України на рівень іiі зовнішньоекономічної безпеки автором проаналізовано взаємозв'язок між динамікою сальдо зовнішньої торгівлі зерном і продуктами його переробки та валовою доданою вартістю секторів економіки. За результатами проведеного аналізу показано негативний вплив сировинної орієнтації вітчизняного агроекспорту на складові ЕБ держави та доведено, що зерновий експорт не спроможний забезпечити жодну зі специфічних функцій стратегічного зернового ринку України. Водночас відтворювальний розвиток IЗР та системи суміжних і пов'язаних до нього ринків, найповніша реалізація інтегрованими ринками базової відтворювальної функції спроможні в умовах глобалізаційних процесів забезпечити здатність національної економіки до сталого та збалансованого зростання, що $\epsilon$ метою і змістом економічної безпеки держави.

Прикладне значення авторських розробок визначається можливістю їх використання державними органами влади в ході наукового обгрунтування та розробки механізму забезпечення економічної безпеки, виборі інструментів впливу на ії рівень. Перспективи подальших досліджень полягають в оцінці векторів впливу інтегрованих товарних ринків на рівень економічної безпеки держави в умовах загальносвітових інтеграційних процесів.

\section{Література}

1. Тимошенко Л. М. Узагальнення концептуальних основ економічної безпеки / Л. М. Тимошенко, Краснікова Н. О. // Вісник Дніпропетровського університету. Серія «Економіка». - 2011. - Вип.5 (4). - С. 77-84.

2. Шлемко В. Т. Економічна безпека України: сутність та напрямки забезпечення: монограф. /В. Т. Шлемко, І. Ф. Бінько. - К.: НІСД, 1997. - 144 с.

3. Глазьев С. Ю. Основы обеспечения экономической безопасности страны - альтернативный реформационный курс / С. Ю. Глазьев // Российский экономический журнал. - 1997. - №1 . - С. 3-16.

4. Gusakov V. G. (2015) "Economic and food security: terms and concepts"/ V.G. Gusakov, E. I. Dereza. I. M. Kulikov and other, available at: http://vocable.ru/dictionary/1249/word/prodovolstvenaja-bezopasnost (Accessed September 07, 2015)

5. Экономическая безопасность / Под. общ. ред. Е. А. Олейникова. - М.: Классика плюс, 1999. - 410 с.

6. Экономическая безопасность: Производство - Финансы - Банки / Под. ред. В. К. Сенчагова. - М.: ЗАО «Финстатинформ», 1998. - 621 с.

7. Шнипко О. С. Види і чинники безпеки ієрархічних економічних систем: теоретико-методологічний аспект / О. С. Шнипко // Актуальні проблеми економіки. - 2006. - №5 (59). - С. 78-85. 
8. Nikishina O. V. (2014) "Sectoral Analysis of Reproduction Processes at the Integrated Grain Market of Ukraine", Nauka i Studia, 1 (111), 105 - 111.

9. Про затвердження Методичних рекомендацій щодо розрахунку рівня економічної безпеки України: Наказ Міністерства економічного розвитку і торгівлі України № 1277 від 29.10.2013 р. [Електронний ресурс] Режим доступу : http://cct.com.ua/2013/29.10.2013_1277.htm. -07.09.2015.

10. Єрмошенко М. М. Національні економічні інтереси: реалізація і захист / М. М. Єрмошенко // Актуальні проблеми економіки. - 2001. - №1-2. - С. 18-24.

11. The official site of National Economic Encyclopedia (2015), "Economic glossary", available at: http://vocable.ru/dictionary/ (Accessed September 07, 2015)

12. Про державну підтримку сільського господарства України: Закон України №1877-IV від 24 червня 2004 p. Редакція від 12.02.2015 p. [Електронний ресурс] - Режим доступу : http://zakon4.rada.gov.ua/laws/show/1877-15. - 07.09.2015 p.

13. The official site of Food and Agriculture Organization of the United Nations (2015), "Publications", available at: http:// http://www.fao.org/publications/en/ (Accessed September 7, 2015).

14. Хорунжий М. Й. Продовольча безпека: соціально-економічна суть, стан і показники / М. Й. Хорунжий // Економіка АПК. - 2001. - №5. - С. 15-20.

15. Буркинский Б. В. Экологизация политики регионального развития / Б.В. Буркинский, Н. Г. Ковалева. - Одесса: ИПРЭЭИ НАН Украины, 2002. - 328 с.

16. Про основи національної безпеки України: Закон України № 964-IV від 19.06.2003 р. Редакція від 12.02.2015 р. [Електронний ресурс] - Режим доступу : http://zakon4.rada.gov.ua/laws/show/964-15. - 07.09.2015.

17. Алтухов А. И. Возможности расширенного воспроизводства в зерновом хозяйстве / А. И. Алтухов // Экономист. - 2004. - №5. - С. 80-88.

18. Офіційний сайт Державної служби статистики України. [Електронний ресурс] - Режим доступу : //http://www.ukrstat.gov.ua/- 07.09.2015 p.

19. Мудрак Р. П. Экспорт украинского продовольствия: состояние, тенденции, причины / Р. П. Мудрак // Экономика Украины. - 2014. - № 5(622). - С. 70-79.

20. Лисюк В. М. Теоретико сутнісний аналіз економічної інтеграції як економічного процесу // В. М. Лисюк, Т. В. Деркач / Економічні інновації. - 2015. - №59. - С. 194-201.

\author{
Никишина О.В. \\ кандидат экономических наук, докторант \\ отдел рыночных механизмов и структур \\ Институт проблем рынка и экономико-экологических исследований НАН Украины \\ Французский бульвар, 29, г. Одесса, Украина, 65044 \\ E-mail: ksenkych@gmail.com
}

\title{
ИНТЕГРИРОВАННЫЙ ЗЕРНОВОЙ РЫНОК В ОБЕСПЕЧЕНИИ ЭКОНОМИЧЕСКОЙ БЕЗОПАСНОСТИ УКРАИНЫ
}

Интегрированный зерновой рынок выполняет специфические функции обеспечения продовольственной и экономической безопасности государства. В ходе исследования автором раскрыто содержание экономической безопасности в плоскости четырех концептуальных подходов: (1) желаемое состояние экономики, (2) обеспечение национальных экономических интересов;(3) защищенность экономических интересов субъектов хозяйствования; (4) эфффективность мер государственного регулирования. Предложено авторское определение категории "экономическая безопасность», объединяющей первый и четвертый концептуальный подходы, а именно: управляемое состояние национальной экономики, вектор изменений которого определяется государственной экономической политикой, ориентированной на обеспечение расширенного воспроизводства составляющих национального продукта и преодоления внутренних и внешних угроз безопасности страны.

Главные направления влияния интегрированного зернового рынка на экономическую безопасность государства проходят через продовольственную и внешнеэкономическую безопасность. Функция зернового рынка по обеспечению продовольственной безопасности реализуется путем его влияния на развитие агропродовольственных рынков экономической системы для обеспечения физической и экономической доступности продовольствия для населения. Интегрированный зер- 
новой рынок одновременно влияет на несколько составляющих экономической безопасности, а именно: продовольственную, социальную, демографическую, производственную, макроэкономическую, финансовую и внешнеэкономическую безопасность. Воспроизводственное развитие базового зернового рынка и системы прилегающих к нему рынков предоставит возможность обеспечить способность национальной экономики к устойчивому и сбалансированному росту, что является смыслом и целью экономической безопасности государства.

По результатам анализа установлено, что сырьевая направленность отечественного агроэкспорта, растущий импорт продовольственных товаров негативно отражаются на всех составляющих экономической безопасности государства, не соответствует национальным экономическим интересам. Результаты оценки влияния интегрированного зернового рынка на уровень внешнеэкономической безопасности свидетельствуют о пассивной форме интеграционной политики Украины. В ходе разработки механизма обеспечения экономической безопасности целесообразно ориентироваться на активную интеграционную политику и реализацию экономических возможностей, предоставленных Украине мировой хозяйственной системой.

Ключевые слова: интегрированный зерновой рынок, экономическая безопасность, продовольственная безопасность, внешнеэкономическая безопасность, национальные экономические интересы, экспорт зерна.

\author{
Nikishina O.V. \\ Ph.D. in Economics, Doctoral candidate \\ Department of market mechanisms and structures \\ Institute of market problems and economic \& ecological research \\ of National Academy of Sciences of Ukraine \\ Frantsuzskiy boulevard, 29, Odessa, Ukraine, 65044 \\ E-mail:ksenkych@gmail.com
}

\title{
INTEGRATED GRAIN MARKET IN ENSURING ECONOMIC SECURITY OF UKRAINE
}

Integrated grain market performs specific functions ensure of food and economic security the state. In course of research the author disclosed the content of economic security in a plane four conceptual approaches: (1) desired state of economy; (2) ensure national economic interest; (3) protection of the economic interests of businesses; (4) effectiveness of measures the government regulation. Proposed the author definition of "economic security» that combines first and fourth conceptual approaches, namely: controlled state of national economy, vector of change is determined by the state economic policy, focused on ensure extended reproduction component national product and overcoming internal and external security threats countries.

Main directions the influence of integrated grain market to the economic security the state run through food security and external economic security. Function of grain market to ensure food security is realized through its influence on development of agro-food markets of economic system to ensure physical and economic availability of food for the population. Integrated grain market simultaneously influence to several components of economic security, namely: food, social, demographic, industrial, macroeconomic, financial and external economic security. Reproduction development of basic grain market and system adjacent markets is able to ensure the ability of national economy to sustainable and balanced growth, that is content and purpose of economic security.

A result of analysis found that raw orientation of national agroexport, growing food imports negatively reflected on all components of economic security the state that does not meet national economic interests. Evaluation results the influence of integrated grain market at level external economic security indicate the passive form of integration policy of Ukraine. During the development of mechanism of economic security is expedient to focus on an active integration policy and implementation of the economic opportunities provided by global economic system of Ukraine.

Keywords: integrated grain market, economic security, food security, external economic security, national economic interests, grain exports. 


\section{References}

1. Tymoshenko, L., \& Krasnikova, N. (2011). Uzahalnennia kontseptualnykh osnov ekonomichnoi bezpeky.

Visnyk Dnipropetrovskoho Universytetu. Seriia «Ekonomika», (5(4)), 77-84.

2. Shlemko, V., \& Binko, I. (1997). Ekonomichna bezpeka Ukrainy: Sutnist ta napriamky zabezpechennia (p. 144). Kiyv: NISD.

3. Hlazev, S. (1997). Osnovu obespechenyia ekonomycheskoi bezopasnosty stranu - alternatyvnui reformatsyonnui kurs. Rossyiskyi Ekonomycheskyi Zhurnal, (1), 3-16.

4. Gusakov, V., Dereza, E., \& Kulikov, I. (2015, July 11). Economic and food security: Terms and concepts. Retrieved August 7, 2015, from : http://vocable.ru/dictionary/1249/word/prodovolstvenaja-bezopasnost

5. Oleinykova, E. (1999). Эkonomycheskaia bezopasnost (p. 410). Moskva: Klassyka plius.

6. Senchahova, V. (1998). Эkonomycheskaia bezopasnost: Proyzvodstvo - Fynansu - Banky (p. 621). Moskva: ZAO «Fynstatynform».

7. Shnypko, O. (2006). Vydy i chynnyky bezpeky iierarkhichnykh ekonomichnykh system: Teoretykometodolohichnyi aspekt. Aktualni Problemy Ekonomiky, (№5 (59)), 78-85.

8. Nikishina, O. (2014). Sectoral Analysis of Reproduction Processes at the Integrated Grain Market of Ukraine. Nauka I Studia, (1 (111)), 105 - 111.

9. Pro zatverdzhennia Metodychnykh rekomendatsii shchodo rozrakhunku rivnia ekonomichnoi bezpeky Ukrainy. (2013, October 29). Retrieved September August 7, 2015, from http://cct.com.ua/2013/29.10.2013_1277.htm.

10. Iermoshenko, M. (2001). Natsionalni ekonomichni interesy: Realizatsiia i zakhyst. Aktualni Problemy Ekonomiky, (1-2), 18-24.

11. The official site of National Economic Encyclopedia. (2015, June 16). Retrieved August 9, 2015, from http://vocable.ru/dictionary/

12. Pro derzhavnu pidtrymku silskoho hospodarstva Ukrainy: Zakon Ukrainy №1877-IV vid 24 chervnia 2004 r. (2015, February 12). Retrieved August 9, 2015, from http://zakon4.rada.gov.ua/laws/show/1877-15.

13. The official site of Food and Agriculture Organization of the United Nations. (2015, July 9). Retrieved August 7, 2015, from http://www.fao.org/publications/en/

14. Khorunzhyi, M. (2001). Prodovolcha bezpeka: Sotsialno-ekonomichna sut, stan i pokaznyky. Ekonomika APK, (5), 15-20.

15. Burkynskyi, B., \& Kovaleva, N. (2002). Ekolohyzatsyia polytyky rehyonalnoho razvytyia (p. 328). Odessa, Odeska: YPRЭЭY NAN Ukraynu.

16. Pro osnovy natsionalnoi bezpeky Ukrainy: Zakon Ukrainy № 964-IV vid 19.06.2003 r. (2015, February 12). Retrieved August 7, 2015, from http://zakon4.rada.gov.ua/laws/show/964-15.

17. Altukhov, A. (2004). Vozmozhnosty rasshyrennoho vosproyzvodstva v zernovom khoziaistve. Ekonomyst, (5), 80-88.

18. Ofitsiinyi sait Derzhavnoi sluzhby statystyky Ukrainy. (2015, May 15). Retrieved August 7, 2015, from //http://www.ukrstat.gov.ua/

19. Mudrak, R. (2014). Eksport ukraynskoho prodovolstvyia: Sostoianye, tendentsyy, prychynu. Ekonomyka Ukraynu, (5(622)), 70-79.

20. Lysiuk, V., \& Derkach, T. (2015). Teoretyko sutnisnyi analiz ekonomichnoi intehratsii yak ekonomichnoho protsesu. Ekonomichni Innovatsii, (59), 194-201.

Received 02 September 2015

Approved 20 September 2015

Available in Internet 26.12.2015 